\title{
Measuring Tourist Satisfaction by the Jordanian Tourism Services in the Area off Um Qais
}

\author{
Marzouq Ayed Al Qeed (Corresponding author) \\ Faculty of Finance and Business \\ Department of Management, The World Islamic Sciences \& Education University \\ PO box 1101, Amman 11947, Jordan \\ E-mail: dr_marzouq@yahoo.com \\ Moayyad A. Fawaeer \\ Department of Management, The World Islamic Sciences \& Education University \\ Amman, Jordan \\ Bader A. Qaid \\ Department of Business Administration, Irbid National University \\ Irbid, Jordan
}

Received: November 16, $2011 \quad$ Accepted: December 12, $2011 \quad$ Published: February 1, 2012

doi:10.5539/ijms.v4n1p150 URL: http://dx.doi.org/10.5539/ijms.v4n1p150

\begin{abstract}
This study lies in the measurement of tourist satisfaction by the Jordanian tourism services provided in the area of Umm Qais tourism in terms of hotel services and the provision of means of transport, restaurants and other services that contribute to the satisfaction of tourists through marketing and promotion through various means.

By returning to the study references and studies related to the research topic and methodology used to prepare the analytical and descriptive identification, we reached out the results that would contribute to the tourists satisfaction with the services provided in the area of Umm Qais through our findings and recommendations.
\end{abstract}

Keywords: Tourist satisfaction, Tourism services, Services marketing

\section{Introduction}

Jordanian tourism sector contributes in the gross local outcome at a rate of $14 \%$ that makes it highly significant as an active economic sector that has effectively activated Jordanian economy. Jordan enjoys many advantages and natural, human elements that turned out it to a touristic destination year around as it needs most of the enjoyments the tourist seeks either therapy, historical, touristic, educational religious and relics, a fact that looks clear through Jordanian tourist profile that contains but not restricted Moderate climate, civilization stamp hot water mineral springs, educational and health foundations, touristic facilities that serve tourists. The Jordanian government has paid up every attention to the internal tourism a well as it serves in supporting the economic cycle and makes no way for foreign currency to go out and re-distribute national wealth to help all different touristic facilities actively operating all through the year of the site that the government paid attention for is the touristic area of Um Qais north of Irbid governorate amongst Oak, Fruit, Olive trees in the heart of the fertile area surrounded by valleys gushing lavish springs and overlooking Tabariya Lake and Golan hills. The study aimed to know how far the Jordanian tourist is satisfied with the services offered there under the very attractive scenes.

\section{Methodology}

\subsection{Study problem}

Um Qais city is one of very important area environment - wise plus its graceful history and represent a refreshing in Summer due to is its evergreen forests all over Irbid governorate (Irbid), also an attractive place for the 
Islamic and Christian relics but it's not utilized well, but here we are concerned to know how far Jordanian costumer is satisfied with the service offered to him.

\subsection{Research hypothesis}

Main Hypothesis - Is there a relation of statistical significance of the level of $(\alpha \leq 0.05)$ between Jordanian tourist and tourism services offered to him at Um Qais?

First secondary hypothesis - Is there relation of statistical significance at the level $(\alpha \leq 0.05)$ between Jordanians tourist and transport and communications at Um Qais?

The second secondary hypothesis - Is there relation of statistical significance at the level of $(\alpha \leq 0.05)$ between Jordanian tourist satisfaction about touristic services offered to him and food, drink services at Um Qais area?

The third secondary hypothesis - Is there relation of statistical significance at the level of $(\alpha \leq 0.05)$ between the services offered to him and other services at Um Qais?

\subsection{Research importance}

it lies in knowing the factors affecting the Jordanian tourist satisfaction with the touristic services offered at Um Qais in relation with internal tourism of one of the most prominent areas in the kingdom, i.e. Um Qais.

\subsection{Research objectives}

it aims at studying the status of the internal situation of internal tourism at Um Qais and to what extent he is satisfied with it in respect to hotel services, transportation, restaurants and else.

\subsection{Study population and sample}

Study population was formed of groups of Jordanian tourist and seeking how far they are satisfied with the services offered to them at Um Qais area. As for the study sample, it was formed of a group of Jordanian tourist and how far they are satisfied with the services offered at Um Qais area, they were (100) tourist

\subsection{Research variables}

\subsubsection{Independent ones}

1). General services offered at Um Qais tourism area.

2). Transportation service in the area and communications

3). Food and drink services in the area.

4). Other services in the area.

\subsubsection{Dependent variable}

Jordanian tourist satisfaction related to tourism services offered at Um Qais area.

\subsection{Study method}

The researchers used the qualitative comprehensive method as it suits best the nature of the study as well

\section{Literatures review}

\subsection{Study by (Dima Akram Salloum), titled by Tourism sector in Jordan from the view point of Ministry of} Tourism and staff, 1998

The study aimed to study that status of tourism sector in Jordan by seeking to know the most attractive sector for tourists and services offered there, positive and negative points. Study samples was (200) staff of Tourism Ministry in Amman and its offices. The researcher used a questionnaire to collect information.

The study revealed a high level and attractive for tourists in Jordan but for satisfaction is average and that positive side is high of which gross revenue is increasing, also income of individuals, foreign currency, infrastructure, development job opportunity available, recreational places as well, but negative points not of significant but one negative only.

\subsection{Study by (Awwad Qwakaza), titled trends and models of Arab tourism in Jordan, (2001)}

The study aimed at knowing how far the Arab tourism place of concern by Jordan Ministry and next by the foreign ones as well especially at time of political crises. The researcher used a lot of ways to get over to study goals so he used a questionnaire of (50) forms for some places that Arab tourists go there in Jordan in a random way one form was given to 10 people; the results showed that tourism in Jordan is seasonal. i.e., high in summer 
but low in other seasons, on the other side Ministry of Tourism and Relics and travel offices, books and magazines are poor in attracting Arab tourists to Jordan.

3.3 Study by (Khaled Maqablah), titled, Evaluation to the status of internal tourism, Mo'ta for research and studies, 2003

The study aimed to identify the nature and dimensions of tourism movement by Jordanians in the golden triangle of tourism: Aqaba, Petra and Wadi Rum. The study distributed (400) questionnaire on the citizens who visit the site and it found out that tourist movement by citizens to the golden triangle is mainly internal not for excursion, family type, groups trips they don't approach tourism and travelling agents but visitors value high the place or site attraction, and they see that touristic services are high to afford by Jordanians, and they found that there is statistical significance between touristic citizen for the site to the golden touristic triangle and the social and job variables.

\section{Theoretical frame}

Tourism scoter It represents one of the economic activities for countries that have tourism sites or relic's sites that people frequent to them by persons as tourists and the entities related to tourism and its project. Tourism can be defined as Human activity and social phenomenon one by individuals moving from their residences to areas away for a period of time not less than (24) hours nor more than one in full year, for tourism except for study or work (world tourism organization, 2001) Tourism in Jordan dealt with lot of fields economic, cultural and media. Economy wise it's very important for econ-development in some areas of Jordan, in media and civilization it offers good opportunity for nations and civilizations to meet and so help nations understand each other (Qawqaza 2001).

\subsection{Tourism components}

Tourists: They are the Humans capacity that the host state accommodates per tourist requirements.

The promoters: They are the people that offer tourism services, detailing all what it can offer to the tourist that he may seek, and which he may like.

Tourism landmarks: They represent tourism types as Religious, pathological, sports, social, marketing adventures, sea shores, Relics. Tourisms (Sammawi 2000), plus there are two other types namely.

1). International tourism: It's the one between a state and crossing the borders of another state.

2). Internal tourism: It's the tourism among the state citizens to its different citizens and sites of tourism sites or tourism landmarks that deserve visit Internal tourism includes citizens movement to tourism sites in their parent country such as Jordanians visit to tourism places and sites such as Petra, Aqaba, Wadi Rum, Jerash, Ajloun, Um Qais, Madaba, Dead Sea and so on, as this type aims to make a person know the relics in Jordan land and provides a big part of rest and enjoyment mainly at the holidays (Obeidat, 2000).

\subsection{Tourism elements}

Tourism had elements so that it can be functional and utilizable and maintained: there are three basic elements for tourism (Maqablah, 2003):

1). Attractions: urge persons to visit a place or sight, either natural, historic, cultural, recreational, religious, which are basic for tourism plus the services offered to the tourist. Anyhow Maqablah and others put a list for the most important elements for tourism attraction namely, climate, natural scenes, service available (National frame and infrastructure) cultural and historical features of the country, easy and available ways of transportation to the site, accommodations shelters, tourism promotion, providing available information's plus, hospitability, dragomen, foreign language for easy communication.

2). Services transportations: make transportation available to the sites either by land, air, sea to reach safely plus the time required.

3). Hospitability: this element is important to attract tourists as welcoming and affection shown by citizens attract the tourist and make him enjoy his vacation and at the same time encouraged to come over again and again.

\subsection{Jordanian tourism substantial}

Jordan has a lot of tourism sites that attract tourists and visitors from all over the world which Abu Rahma has summarized in the following points (2001): 


\subsubsection{National substantial}

Natural profile is the highest in tourism attraction in Jordan, geographical site, different and variety of relief's good climate attracts visitors that a tourist enjoys.

\subsubsection{Historical and civilization substantial}

Jordan is considered an open museum due to historical fantastic cultural features that relate to the many civilizations that passed through it. The visit to relics, historical places are considered main factor for tourism attraction that urge lot of visitors to come down.

\subsubsection{Tourism services}

Tourism services available in Jordan help in attracting tourist, and enjoy the site, in addition to services offered to them and meet their wishes and tastes on different levels and culture, as services offered go in line with new types, which escalate the tourism level in Jordan (2007).

1). Hotels Services, they include all new types that relate to tourism, so the ministry of tourism encouraged building hotel to meet the progressive increase of visitors.

2). Tourism and travel offices and tourism office play important role in activating tourism, in and out of Jordan and help tourist to come downs, plus rosining trips inside Jordan and outside for individuals groups related to marketing, transportations, accommodators, food and drink and through by Media and direct communication.

3). Rent - car tourism offices, these offices help renting cars that transport tourists between tourism sites.

4). Tourism Dragoman: the dragoman plays important role in the tourism activity by identity, the tourism substantial are available in Jordan and highlighting it in a well coordinated way and magnify the benefit that tourist requires through his visit to tourism places.

5). Orientals Curiosities Trade: in Jordan there are a lot of Orientals curiosities that sell such armaments and memorable gifts to the tourists such as copper utensils shells, silver made items, woodworks, potteries, traditional clothes, embroideries and traditional carpets.

6). Tourist's transportation companies: these companies share in facilitating tourists transportation and tourists groups and arranging internal tourists trips.

\subsection{Anecdote about the tourism at Um Qais}

\subsubsection{Introduction}

Um Qais is considered one of the most beautiful cities in Irbid governorate, scores of persons visit. It's one of the best summer retreats in Jordan particularly it's a source for tourists attraction due to many relics, antiquities, forestry, water springs, valleys, rich with relics fruitful gardens and other places that visitor frequent to them (www.alra.com).

\subsubsection{The site}

Um Qais city is situated in East-North area of Irbid Governorate, Bani Kinana district on a hill of 378m high over the sea level, bordered from the north by Yermouk river that separates it from Jordan mound (knoll) and from the west by Wadi Al Arab and from the East by Tabariya lake (Al Sa'd 72) while the city falls in the western part of the town.

\subsubsection{Tourism substantial in Um Qais}

1). Archaeological sites: Um Qais has a lot of antiquity sites such as Decapolis that is a antiquity city in full. It has all city elements, top of them are: the western amphitheatre. It's a Roman stage of black Basalt just $50 \%$ of it has been refurbished but at present it can accommodate 500 persons plus an orchestra for artful and stage (theatre) teams. It's considered one of the most important elements that attract tourists.

2). Tiled streets: There are (3) streets up till now, the Decamonis. It crosses the city from east to west from (Houran east up to Tabariya west. Also there is Al Kardio street, north south, opposite commercial market: vaulted Rooms its (20) ceiling rooms, barrel wise was used as commerce rooms. (12) Have restored and the other (8) later.

3). Basilica courtyard: It's a Roman rectangle courtyard in the north of the west amphitheatre overlooking the courtyard, was used as a public courtyard in the Roman city.

4). The Octagons church: This church has (8) side with (8) Basalt poles in the middle.

5). Fairies Road: Falls in the Decapolis street. 
6). The temple: It's an idolatry temple of four pillars in the front, has been restored lately, Corinthian style.

7).Tunnels and trenches: They are trenches sculpted from rocks under the earth that were used under the city.

8). Royal cemetery: Falls west of city, it is an artful peace (curiosity) in the city, Basaltic stones well-cut and Basalt stones, Corinthian style.

9). Octagons Building: Last item discovered in the city was of (8) side area inside the courtyard tiled, leads to the general courtyard. It's the municipality building, the oldest one found in Al Sham countries, also there is an Oval church, drainage network for water, city gates, Horse racing field, the north amphitheatre, pillars cylinder like hexagon in shape in the shape of heart anyhow, all these relics are just one third of city archaeology pieces.

\section{Display and analysis of the study sample answers}

\subsection{Study reliability}

To make sure of tool validity the researcher used Cronbakh Alpha equation on the original sample to know the coefficient of the reliability of the internal context of the tool as a whole it was $(0.9054)$.

\subsection{Statistical treatment}

Statistical parcels program (SPSS) was used in handling the data, then extracting the arithmetical means and SD of the study tool fields and for the tool as a whole and applying (one sample T-test).

\subsection{Finding}

\subsubsection{Tool reliability}

For realizing that study tool is reliable, Cronbakh Alpha equation was applied to all study tool Paras, table explains that:see table 1 .

From Table (1) that all Cronbakh coefficients, for Paragraphs of study (0.9154), show that the tool is valid. This part includes the results of this study that aims (Measuring tourist Satisfaction by the Jordanian Tourism Services in the Area off Um Qais); it also includes description for the sample individuals per the variables of the character, gender, age, education level, monthly income and results to be exposed.

5.3.2 Results related to the personal variables (see Table 2)

From table 2: it seems that the highest percentage was for females which was 61.0 and for male 39.0.

5.3.3 Distribution of the answers of sample individuals per age

From the table 3: the highest percentage was 33.0, it was from 21 to less than 31 years, then the percentage (24.0) it was (31) to less than (40) years. The lowest percentage (8.0) and it was over 50 years.

\subsubsection{Distribution of answers of sample individuals per education level}

From table No 4, that the higher percentage was 35.0 for the Diploma, next 30.0 (high school and lower) next 27.0 for Bachelor degree, the lowest percentage was for higher studies.

\subsubsection{Distribution of answers of sample individuals per education level}

From Table No 5 shows that the higher percentage was 43.0 it was from 300-500J Jordan D these percentage 300, (less than 300 Jordan Dinar) and the lowest percentage was 27.0 (it was over 500 Jordan Dinar).

\subsubsection{Distribution of sample individuals per residence place}

Table No 6 shows that the highest percentage was 74.0 and it was for the village, and the lowest percentage 26.0, was for the city.

\subsubsection{Study hypothesis}

\section{1). The main first Hypothesis:}

There is relationship of statistical significance at the level of $(\alpha \leq 0.05)$ between the satisfaction of Jordanian tourist and the services offered to him at the tourism area of Um Qais.

\section{2). First secondary Hypothesis:}

There is relationship of statistical significance at the level $(\alpha \leq 0.05)$ between satisfaction of Jordanian tourist for the services offered to him and services of transportation and communications at tourism area of Um Qais. To make sure of validity of the first secondary hypothesis, the following arithmetic averages, have been extracted and the (SD) of the Paragraphs (services of transportation and communications) and the grand total of them, and test of (one sample t- test) was applied to the field and to the two tables ( $7 \& 8)$ that explain: 
To make sure of validity of the first secondary hypothesis, the following arithmetic averages, have been extracted and the (SD) of the Paragraphs (services of transportation and communications) and the grand total of them, and test of (one sample t- test) was applied to the field and to the two tables ( $7 \& 8)$ that explain:

From table No. 7, it seems that higher arithmetic average was 3.20 for Para (2), next was 3.13 for Para (3), lowest percentage was 3.11, for Para (1). Total was 3.15.

From table No. 8 it seems that the value was 1.17 which is not statistical at the level of the significance $(\alpha=0.05)$ and the value of the SD test of the fifth gradation (3), this means that no services of Trans and com. available.

5.3.8 Second secondary hypothesis

There is relationship of statistical significance at the level of $(\alpha \leq 0.05)$ between the Jordanian customer satisfaction for the services offered to him and food and drink services at the touristic area of Um Qais, to make sure of the validity of the second secondary hypothesis, arithmetic average and Standard Deviation were extracted for food and drink services and their grand total, and applying one sample (t-test) to the field and the two tables (9-10) explain that:

Table (9) shows that the highest arithmetic average was $3.22 \%$ for Para (1) next were the percentage (2.65) for Para (3). Lowest was 2.57 for Para (2). Grand total was (2.81).

Table (10) shows that T-value was $(-1.07)$ which has no statistical significance at the level $(\alpha=0.05)$ and the degree of the standard fifth gradation was (3) which indicates no food or drink services.

\subsubsection{Third secondary hypothesis}

There is statistical significance relation at the level $(0.05=a)$ shows the tourist significance in Jordanian on the serviced offered to him and food and drink services at the tourism area at um Qais, to make sure of the validity of the third secondary hypo, Arithmetic means and SDs have been extracted for Para's (other services) and the total amount of them, one sample t-test was applied on the field and the two tables (11-12) show that:

Table (11) shows that highest Arithmetic. mean was 2.89 for Para (1) recreations means, next Para's (6\&8) cleanliness and parking areas, next entry to touristic sites, lowest was Para (3) lack of information (2.76).

Table (12) shows that T. value was $(-2.1)$ at the significance level $(\alpha=0.05)$ and the Standard Deviation is (3) which means that there are other services.

\subsubsection{Results summary}

No relations of significant value at the level of $(\alpha=0.05)$ for trans and com. And the Standard Deviation grading was (3) where (T) value was (1.17) at a statistical significance of 20.24. No statistical value at the level of $(\alpha=0.05)$. There are food and drink services and SD (3) where t-value was (1-1.7) at a statistical significance of $(0.09)$.

There is relation of statistical significance at the level of $(\alpha=0.05)$ and other services at Standard Deviation test (3) of T-value (-2.1) at statistical significance of (0.03).

\section{Recommendations}

1). Providing parking for transport and communication means.

2). Making publication related to tourism sites.

3). Full controls on restaurants to make sure of good food services.

4). Restoration of tourism sites and controlling cleanliness and services so as to be more attractive.

5). Place road signals directing to tourism sights that help tourist to the place he seeks.

6). Making local community share by making it a word of tourism significance.

7). Marketing the area by promotions and specialized programs with other concerned departments.

8). Contract agreements with the private sector to promote the region both internally and externally.

9). Improve services continuously to gaining the approval of the tourist.

10). Training of personnel working in the tourism services to manage marketing through their involvement in the courses of specialized training.

\section{References}

Abu Ruman As' ad. (2010). Tourism in Jordan. Ithraa Publishing, Amman, Jordan. 
Abu Ruman As'ad. (2002). Measuring the quality of services provided in the McDonald's restaurants in Amman. Al-Domur, Hani and Hamid T. (2002). Service Marketing, Wael Publishing. Amman, Jordan.

ALQeed, M and others. (2011). Tourism Principles. Ithraa Publishing, Amman, Jordan.

Arab Organization for Tourism (2009). [Online] Available: www.arabictourism.org

Bhatia, A.K. (1991). Internatioal Tourism: Fudementals and Practices. New Delhi, Sterling publishers 15pvt.ltd

Dima Akram Salloum (1993). Tourism sector in Jordan. Master degree thesis.

Khaled Maqableh and others (2009). Tourism Industry in Jordan. Wael Publishing, Amman, Jordan

Khalid Maqableh (2003). Evaluations of the reality and dimensions of internal tourism in the golden touristic triangle as seen by Jordanian visitors.

Kotler, P., and Keller, K. (2007). MarketingManagement. New Jersey: Pearson Education.

Markin, Rom(2003). Marketing:Strategy and Management (3th ed.). New York: John Willy and Sons.

Middleton, Victor T. (2001). Marketing In Travel and Tourism. Butterworth Publishing Co. Oxford.

Ministry of Tourism and Archeology (2010). Amman-Jordan

Obeidat Mohm'd (2009). Tourism Marketing. Wael Publishing, Amman, Jordan.

Qawqaza, Awwad (2001). Types and trends of Arab Tourism in Jordan.

Royal Scientific Society. (2000). Tourism Economics in Jordan: Essential Facilities and Marketing. Amman, Jordan.

Samawi, H. (2000). Types and trends of tourism at Aqaba area. Journal of social science. Jordan university

Tai, Hameed, (2002). Factors affecting food preference in the decision from the viewpoint of customers (analytical field study - the Greater Amman Municipality).

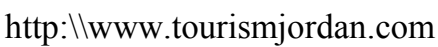

http: \www.alrai.com

Table 1. Results of applying equation (Cronbach alpha) on all paragraphs of the study

\begin{tabular}{|c|c|}
\hline Study tool & Value of Cronbakh coefficient Alpha \\
\hline Whole Field & 0.9154 \\
\hline
\end{tabular}

Table 2. Distribution of sample answers per gender variable

\begin{tabular}{|l|c|c|}
\hline Gender & Frequency & Percentage \\
\hline Male & 39.0 & 39.0 \\
\hline Female & 61.0 & 61.0 \\
\hline Total & 100 & 100 \\
\hline
\end{tabular}

Table 3. Distribution of the answers of sample individuals per age

\begin{tabular}{|l|c|c|}
\hline Age & Frequency & Percentage \\
\hline Less than 20 years & 14.0 & 14.0 \\
\hline From 21 to less than 30 years & 33.0 & 33.0 \\
\hline From 31 to less than 40 years & 24.0 & 24.0 \\
\hline From 41 to less than 50 years & 21.0 & 21.0 \\
\hline Over forty years & 8.0 & 8.0 \\
\hline Total & 100.0 & 100.0 \\
\hline
\end{tabular}


Table 4. Distribution of answers of sample individuals per education level

\begin{tabular}{|l|c|c|}
\hline Education Level & Frequency & Percentage \\
\hline High school and lower & 30.0 & 30.0 \\
\hline Diploma & 35.0 & 35.0 \\
\hline Bachelor degree & 27.0 & 27.0 \\
\hline Higher studies & 8.0 & 8.0 \\
\hline Total & 100.0 & 100.0 \\
\hline
\end{tabular}

Table 5. Distribution of the answers of sample individuals per the monthly incomes

\begin{tabular}{|l|c|c|}
\hline Monthly Income & Frequency & Percentage \\
\hline Less than 300 Jordan Dinar & 30.0 & 30.0 \\
\hline 300 - 500 Jordan Dinar & 43.0 & 43.0 \\
\hline Over than 500 J D & 27.0 & 27.0 \\
\hline Total & 100.0 & 100.0 \\
\hline
\end{tabular}

Table 6. Distribution of sample individuals per residence place

\begin{tabular}{|l|c|c|}
\hline Residence place & Frequency & Percentage \\
\hline Village & 74.0 & 74.0 \\
\hline City & 26.0 & 26.0 \\
\hline Total & 100.0 & 100.0 \\
\hline
\end{tabular}

Table 7. Arithmetic means and standard deviations of the paragraphs of transport, communication, and the sum total of the two

\begin{tabular}{|l|c|c|c|c|}
\hline No. & Paragraphs & Average & $\begin{array}{c}\text { Standard } \\
\text { Devation }\end{array}$ & Rank \\
\hline 1 & Availability of trans. And com. Means & 3.11 & 1.34 & 3 \\
\hline 2 & Availability of com. Services & 3.20 & 1.45 & 1 \\
\hline 3 & Trans. Cost & 3.13 & 1.35 & 2 \\
\hline Total & & 3.15 & 1.95 & - \\
\hline
\end{tabular}

Table 8. Results of applying (one sample t-test) transport and communication services

\begin{tabular}{|c|c|c|c|c|}
\hline $\begin{array}{c}\text { First secondary } \\
\text { hypo. }\end{array}$ & $\begin{array}{c}\text { Arithmetic } \\
\text { Average }\end{array}$ & $\begin{array}{c}\text { Standard } \\
\text { Deviation }\end{array}$ & T. value & $\begin{array}{c}\text { Statistic } \\
\text { significance }\end{array}$ \\
\hline $\begin{array}{c}\text { Transportation \& } \\
\text { communication } \\
\text { Services }\end{array}$ & 3.15 & 1.25 & 1.17 & 0.24 \\
\hline
\end{tabular}

Table 9. Arithmetic means and standard deviations of the paragraphs of the food and beverage services and the sum total of the two

\begin{tabular}{|l|c|c|c|c|}
\hline No. & Paragraphs & Average & $\begin{array}{c}\text { Standard } \\
\text { Deviation }\end{array}$ & Rank \\
\hline 1 & Food and drink service available & 3.22 & 1.31 & 1 \\
\hline 2 & Quality of food and service services & 2.57 & 1.34 & 3 \\
\hline 3 & Cost of food and drink & 2.65 & 1.38 & 2 \\
\hline Total & & 2.81 & 1.10 & - \\
\hline
\end{tabular}

Table 10. Results of applying (one sample t-test) food and drink services

\begin{tabular}{|c|c|c|c|c|}
\hline Second secondary hypo. & $\begin{array}{c}\text { Arithmetic } \\
\text { Average }\end{array}$ & $\begin{array}{c}\text { Standard } \\
\text { Deviation }\end{array}$ & T. value & $\begin{array}{c}\text { Statistic } \\
\text { significance }\end{array}$ \\
\hline Food and drink Services & 3.2 .81 & 1.10 & -1.07 & 0.09 \\
\hline
\end{tabular}


Table 11. Arithmetic means, SD's of the Paragraphs of other services and the total amount of them

\begin{tabular}{|l|c|c|c|c|}
\hline No. & Paragraphs & Average & $\begin{array}{c}\text { Standard } \\
\text { Deviation }\end{array}$ & Rank \\
\hline 1 & Availability of Recreation & 2.89 & 1.42 & 1 \\
\hline 2 & Availability of Security & 2.76 & 1.35 & 4 \\
\hline 3 & Information Availability & 2.56 & 1.28 & 7 \\
\hline 4 & Entry fees & 2.60 & 1.33 & 6 \\
\hline 5 & Cleanliness level & 2.77 & 1.35 & 3 \\
\hline 6 & Site attraction & 2.87 & 1.43 & 2 \\
\hline 7 & Direction sign Boards & 2.74 & 1.38 & 5 \\
\hline 8 & Parking places & 2.87 & 1.32 & 2 \\
\hline Total & & 2.76 & 1.12 & - \\
\hline
\end{tabular}

Table 12. Results of applying test one sample t-test, food and drink

\begin{tabular}{|c|c|c|c|c|}
\hline Third secondary hypo. & Average & $\begin{array}{c}\text { Standard } \\
\text { Deviation }\end{array}$ & T. value & $\begin{array}{c}\text { Statistic } \\
\text { significance }\end{array}$ \\
\hline Other Services & 2.76 & 1.12 & 2.1 & 0.03 \\
\hline
\end{tabular}

